\title{
Larerstudenters bevisstgjøring av sammenhengen mellom begrepsbruk og oppfattet annerledeshet
}

\author{
Kari Spernes \\ Høgskolen $i$ Østfold, Norge
}

\section{SAMMENDRAG}

Selv om skolens verdigrunnlag bygger på likeverd mellom elevene og nulltoleranse for diskriminering, er diskriminering av minoriteter likevel et problem i skolen. Dette tilsier at lærerutdanningene må jobbe aktivt med holdningsskapende arbeid. Hensikten med denne artikkelen er å undersøke hvorvidt en oppgave om begrepsbruk kan bevisstgjøre grunnskolelærerstudenter hvordan begrepene som brukes kan bidra til generalisering og stereotypisering. Et omdreiningspunkt $\mathrm{i}$ analysen er hvordan generalisering, stereotypisering og mulige fordommer kommer til uttrykk gjennom refleksjon rundt begrepene 'foreldre' og 'innvandrerforeldre'. Resultatene viser at studentenes assosiasjoner er svært ulike avhengig av hvilket begrep de har reflektert rundt. De studentgruppene som fikk begrepet foreldre knytter sine assosiasjoner i hovedsak til foreldrerollen, mens gruppene som fikk begrepet innvandrerforeldre relaterer sine assosiasjoner i hovedsak til disse foreldrenes språklige og/eller kulturelle bakgrunn. Med utgangspunkt i begrepene er studentene også på ulikt vis opptatt av utfordringer i skole-hjemsamarbeidet. Datamaterialet som artikkelen bygger på, er resultatene fra selve studentoppgaven samt lærerstudentenes refleksjoner etter at de har blitt presentert for resultatene fra oppgaven.

Nøkkelord: begrepsbruk; begrepsoppgave; generalisering; stereotypisering

Mottatt: Februar, 2020; Antatt: Mars, 2021; Publisert: Juni, 2021

\section{ABSTRACT \\ Student teachers' awareness of the connection between concepts and perception of otherness}

School's values are based on equality between students and zero tolerance for discrimination, but generalization and stereotyping related to minorities is still a school problem. This is a signal to teacher education about the importance of enabling student teachers to reflect on their attitudes. The purpose of this article is to investigate whether an assignment, with focus on the concept 'parents' and 'immigrant parents', can make student teachers aware of how the concepts they use can possible contribute to generalization and stereotyping. The results show that the students' 
conceptualizations are clearly different, depending which of the two concepts they reflected upon. The groups that discussed the concept 'parents' mainly reflected on various aspects of the parental role, while the groups that got the concept 'immigrant parents' made associations mainly related to the parents' ethnic, cultural and linguistically background and challenges in home-school cooperation. The data, on which the article is based, is the result of the student assignment and the students' reflections (audio recorded and transcribed) after they were presented the result of the assignment.

Keywords: generalisation; stereotyping; student-assignment; terminology

\section{Innledning}

Ifølge Antirasistisk senter (2017) er barne- og ungdomsskolen den samfunnsarenaen hvor flest ungdommer melder fra om opplevd rasisme. Forskning viser også at elever med innvandrerbakgrunn opplever generalisering og stereotypisering i skolen (se f.eks. Røthing, 2014; Spernes, 2014a, 2014b), og skolens lærebøker inviterer i liten grad til «maktkritisk undervisning» om gruppebaserte fordommer (Røthing, 2015, s. 72). Opprettelsen av Dembra (Demokratisk beredskap mot rasisme og antisemittisme), kan forstås slik at Kunnskapsdepartementet har sett nødvendigheten av at skolen arbeider systematisk for å bekjempe negative holdninger til mennesker med ulik religiøs og kulturell bakgrunn (Lenz et al., 2016; Utdanningsdirektoratet, 2016).Viktigheten av at også lærerstudenter bevisstgjøres egne holdninger framheves av pedagogikklærere i en kartlegging utført av Universitet i Stavanger (Thomassen et al., 2017). De framhever at det er spesielt viktig å være bevisst egne holdninger i samarbeidet med foresatte.

I min studie bygger jeg på en gruppeoppgave gjennomført av grunnskolelærerstudenter. Gruppeoppgaven er opprinnelig utarbeidet av en videreutdanningsstudent som ønsket, på bakgrunn av egne erfaringer, å undersøke hvordan begrepsbruken i personalet kunne bidra til generalisering og en stereotyp forståelse av enkelte foreldre. Oppgaven er enkel, men ifølge studenten bidro den til at kollegaene ble bevisstgjort egne forestillinger. Med tillatelse fra denne studenten har jeg brukt oppgaven $\mathrm{i}$ egen undervisning. Jeg spør hvorvidt en oppgave der lærerstudenter reflekterer over begrepene foreldre og innvandrerforeldre, kan brukes for bevisstgjøring av sammenhengen mellom begrepsbruk og oppfattet annerledeshet.

Datamaterialet i denne studien består av resultatene fra selve studentoppgaven samt studentenes refleksjoner etter at de har blitt presentert for resultatene av oppgaven. Metodedelen presenterer derfor oppgaven samt beskriver og begrunner innsamling av data og analyseprosessen. I analysen presenteres og diskuteres studentenes assosiasjoner til begrepene, og deretter er det studentenes refleksjoner over resultatet av oppgaven som er gjenstand for analyse. Jeg hevder avslutningsvis at oppgaven er egnet for lærerstudenters bevisstgjøring av sammenhengen mellom begrepsbruk og oppfatningen av foreldre (og elever) i skolesammenheng. Først presenterer jeg studiens analytiske rammeverk som bygger på sammenhengen mellom ord og tanke samt hvordan begrepsbruk og kategorisering av sosiale grupper er med på å skape en forståelse av virkeligheten. 


\section{K. Spernes}

\section{Virkeligheten forstås gjennom valg av begreper}

Vygotsky (2014), som er opptatt av sammenhengen mellom tenkning og tale, hevder at mennesket oppfatter virkeligheten gjennom de begrepene vedkommende har tilegnet seg. Dale (1993) poengterer at begreper er generaliseringer som brukes for å forstå sammenhenger, og han omtaler derfor begreper som "standardisert mening» (s. 62). Kjeldstadli (2008) ser begrepsbruk i sammenheng med global migrasjon. Han hevder at valg av ord innebærer en tolkning, og at denne tolkningen bidrar til en skapt virkelighet.

Gullestad (2002) er opptatt av hvordan enkelte begreper bidrar til kategorisering av sosiale grupper. Hun bruker som eksempel at ved å kategorisere noen som 'innvandrere' så blir forståelsen av en gruppe mennesker "ureflekterte selvfølgeligheter» (s. 42) som igjen bidrar til generalisering og stereotypisering. Kategoriene utløser følelser og "Hvilke følelser som utløses [...] er langt på vei avhengig av [...] hva slags forestillinger denne kategorien bringer med seg» (s. 42). Kategorisering av mennesker bidrar også til en dikotomisering som skaper et skille mellom 'oss' og 'de andre', og dette gir majoriteten makt til ikke bare å definere en gruppe mennesker men også til «å skape dem» (Gullestad, 2002, 43).

Gadamer (2010) konstaterer at menneskets forståelse inneholder både positive og negative fordommer, og han forklarer dette med at det menneskelige intellektet er for svakt til å kunne manøvrere uten en form for forforståelse. Ifølge Gullestad (2002) kan kategoriene som mennesker plasseres i bekrefte fordommer fordi "Alle er 'blinde slaver' av sine fordommer» (s. 165). Hun påpeker imidlertid at dersom mennesker reflekterer over egne fordommer slik at de blir bevisste, så vil det være mulig å fjerne fordommer som bidrar til stereotypisering av etniske minoriteter. Devine (1989) er i likhet med Gullestad opptatt av etniske fordommer. Hun hevder at de fleste mennesker har stereotypier knyttet til minoritetsgrupper og at disse automatiseres i møte med mennesker fra etniske minoriteter, men hun poengterer at mange klarer å kontrollere følelsene sine slik at fordommene ikke kommer til uttrykk, og at fordomsfulle holdninger derfor ikke nødvendigvis bidrar til fordomsfulle handlinger.

Etniske fordommer kan selv om de ikke utløser konkrete handlinger likevel bidra til generalisering og stereotypisering av etniske minoriteter (Allport, 1979). Allport (1979) framhever derfor viktigheten av holdningsskapende arbeid for å bevisstgjøres egen forforståelse. Han gjør det klart at både kognitiv og emosjonell intelligens er viktig $\mathrm{i}$ holdningsarbeid, men at den emosjonelle intelligensen er mest sentral. Jeg vil videre vise hvordan en begrepsoppgave forsøker å trigge lærerstudenters emosjonelle intelligens når de bevisstgiøres hvordan begrepet innvandrerforeldre eventuelt kan bidra til generalisering og stereotypisering av foreldre med innvandrerbakgrunn.

\section{Metode}

Empirien i denne studien består av en begrepsoppgave samt en refleksjon over resultatet av oppgaven. Studien kan slik jeg ser det, forstås som et intervensjonspreget design, men det er viktig å presisere at både oppgaven og refleksjonene i etterkant 
var del av ordinær undervisning og ikke planlagt som et forskningsprosjekt. Gruppeoppgaven er en begrepsoppgave som har til hensikt å bevisstgiøre lærerstudenter hvordan begreper som brukes i skolen kan bidra til generalisering og stereotypisering, og målet med oppgaven er dermed å skape en endring (jf. Midgley, 2000). Endringen kan være at studentene blir mer bevisst hvordan de bruker begrepet innvandrerforeldre (og tilsvarende begreper som for eksempel, flerkulturelle og minoritetsspråklige foreldre/elever) slik at de møter foreldre (og elever) som enkeltindivider og ikke som representanter for en gruppe.

Undervisningsopplegget er som sagt en begrepsoppgave, og begrepsoppgaven er gjennomført blant studenter ved grunnskolelærerutdanningen i oppstarten av det valgfrie emnet Flerkulturell pedagogikk i 3. studieår. Studentene fikk følgende instruksjon:

Dere deles i seks grupper. Hver gruppe får et ark hvor det står et begrep. Dere skal ikke fortelle de andre gruppene hvilket begrep dere har fătt. Skriv nye begreper/ korte setninger som viser hvilke assosiasjoner dere får når dere hører begrepet, men ikke skriv selve begrepet. Til slutt skal gruppas assosiasjoner skrives inn i lærerens PowerPoint. Dere får 15 minutter til oppgaven.

Gruppe 1, 3 og 5 fikk begrepet foreldre og gruppe 2, 4 og 6 fikk begrepet innvandrerforeldre, men studentene fikk ikke vite at det kun var to begreper. Det var 16 studenter som deltok, tre menn og 13 kvinner. Studentene ble delt i seks grupper som hver bestod av to eller tre studenter. Mennene ble fordelt på tre av gruppene. Med utgangspunkt i språk, navn og/eller hudfarge som uttrykk for bakgrunn, antar jeg at ingen av studentene har innvandrerbakgrunn, noe som muligens kunne hatt betydning for gruppas assosiasjoner. Det ville vært en fordel med flere studenter i hver gruppe fordi i en gruppesamtale vil innspill fra ett av gruppemedlemmene gi assosiasjoner til de andre som igjen fører til at flere perspektiver løftes fram (Repstad, 1998). Jeg valgte imidlertid å ha flere grupper slik at det var mulig å observere eventuelle systematiske forskjeller mellom gruppene.

Tilbake i plenum ble gruppas assosiasjoner ${ }^{1}$ skrevet i en tabell hvor hver kolonne hadde gruppenumrene som første rad. Tabellen ble vist for studentene, og de ble spurt om de gjorde seg noen tanker om hvilket begrep hver enkelt gruppe hadde fått. Flere sa at det var likheter i annenhver kolonne. Flere sa også at de trodde gruppe 1,3 og 5 hadde fătt begrepet foreldre og at gruppe 2, 4 og 6 hadde fått noe med innvandring. Jeg fortalte så at oddetallgruppene hadde fått begrepet foreldre og at partallgruppene hadde fått begrepet innvandrerforeldre.

Studentene ble videre presentert for to spørsmål som de skulle samtale om i de samme gruppene: 1) Hvilke tanker får dere når dere ser resultatet av oppgaven? 2) Kan denne oppgaven brukes for bevisstgjøring av egne holdninger og mulige

\footnotetext{
${ }^{1}$ Videre brukes betegnelsen assosiasjoner for de begrepene studentene skrev i tabellen slik at det er et tydelig skille mellom begrepene studentene skulle reflektere rundt ('foreldre' og 'innvandrerforeldre') og assosiasjonene til disse begrepene.
} 


\section{K. Spernes}

fordommer? I ettertid har jeg sett at det andre spørsmålet burde vært fjernet eller eventuelt vært formulert annerledes. Spørsmålet kan ha bidratt til at studentene framstår som fordomsfulle, og jeg vil presisere at det ikke har vært hensikten med oppgaven. Spørsmålet kan også ha bidratt til at studentene i samtalen ble mer opptatt av egne og hverandres holdninger enn hvordan selve begrepet kan bidra til generalisering og en stereotyp forståelse av enkelte foreldre.

Det ble satt av 15 minutter til gruppesamtalen, og for at studentene skulle huske hva som stod i tabellen under samtalen, ble tabellen med begrepene gjort tilgjengelig i Canvas. Gruppesamtalen ble tatt opp på lydfil, noe studentene var vant til i forbindelse med refleksjonsoppgaver i gruppe. Det er også etablert praksis at lydfiler, slik det ble gjort her, legges i Canvas slik at studentene får tilgang til hverandres gruppesamtaler. Resultatet fra oppgaven var i utgangspunktet ikke tenkt brukt i forskningssammenheng, og studentene fikk derfor spørsmål om deltakelse i etterkant av at oppgaven var gjennomført. Jeg ser at samtykke til deltakelse ideelt sett skulle vært avklart med studentene på forhånd (jf. De nasjonale forskningsetiske komiteene, 2021a), men det var innholdet i samtalene som gjorde at jeg ble interessert i å undersøke studentenes refleksjoner mer inngående. Før studentene ga samtykke fikk de derfor informasjon om hensikten med forskningsprosjektet, hvordan empirien ville bli brukt, at alle data ville bli behandlet konfidensielt og i samsvar med personvernregelverket og at lydfilene ville bli slettet etter at de var transkribert. Det kan diskuteres om det ville påvirket resultatene om studentene hadde vært klar over at oppgaven skulle bli brukt i forskningsøyemed.

Prosjektet var godkjent av NSD, men ut over juridiske vurderinger følger det mange forskningsetiske utfordringer ved å forske på egne studenter (jf. De nasjonale forskningsetiske komiteene, 2021b). Selv om alle studentene ga samtykke til deltakelse, kan det reises spørsmål ved hvor frivillig dette samtykket egentlig var. Det asymmetriske forholdet mellom meg som lærer og studentene og at jeg er den som vurderer og karaktersetter studentenes innsats i faget, kan ha bidratt til at studentene følte et visst press for å delta. I tillegg til å presisere at deltakelsen var frivillig vektla jeg derfor at deltakelse / ikke deltakelse ikke ville påvirke mitt forhold til dem som studenter eller vurderingen av deres innsats i faget. En annen forskningsetisk utfordring er forholdet mellom å være en uavhengig forsker kontra å være lærer til studentene. At oppgaven, som er utgangspunktet for empirien i denne teksten, ble gjennomført den første undervisningsdagen i faget, at jeg ikke kjente studentene fra tidligere og at det ikke var mulig for meg å gjenkjenne studentene i de transkriberte samtalene, bidro til at innholdet i empirien ikke ble knyttet opp mot den enkelte student.

Jeg vil poengtere at hensikt med denne studien ikke har vært å kritisere studentene eller deres uttrykte holdninger, men å undersøke hvordan oppgaven kan bidra til bevisstgjøring av sammenhengen mellom begrepsbruk og oppfattet annerledeshet. Av anonymitetshensyn gis det ikke opplysninger om årskull, i og med at det vil være enkelt å gjenkjenne institusjonen jeg arbeider ved. Av samme grunn brukes konsekvent hunkjønn når det henvises til studentenes utsagn i teksten. 
Datamaterialet i denne studien består altså av studentenes assosiasjoner knyttet til begrepet foreldre eller innvandrerforeldre samt gruppesamtalene relatert til resultatet av begrepsoppgaven. Antall assosiasjoner gruppene noterte varierte fra 4 til 16, og tilsammen ble det notert 62 assosiasjoner til de to begrepene. Hvert lydopptak er på 8 til 12 minutter, og i alt er det 14 transkriberte sider. Analyseprosessen har en skrittvis induktiv-deduktiv tilnærming (jf. Tjora, 2017). Det ble foretatt en tematisk analyse, både innenfor hver enkelt gruppe og mellom gruppene. Studentenes assosiasjoner (begrepene i tabellen) ble systematisert i tre kategorier (jf. Bryman, 2016):

(i) 'foreldrerollen' (hvilket ansvar og hvilken oppgave en person har som forelder), (ii) 'foreldres bakgrunn' (opplysninger om en person som ikke har betydning for foreldrerollen) og (iii) 'samarbeid skole-hjem' (dimensjoner som kan ha betydning for lærerens samarbeid med foreldrene). Koding av gruppesamtalene bidro til kategoriene: (i) vektlegging av 'innvandrer' i begrepet innvandrerforeldre (problematisering og mulige årsaker), (ii) forskjellighet som standard blant alle foreldre og (iii) studentenes refleksjoner rundt selve oppgaven.

\section{Studentenes refleksjoner}

Resultatdelen består av to delkapitler. Det første delkapitlet presenterer en analyse av studentenes assosiasjoner relatert til begrepene foreldre og innvandrerforeldre. I det andre delkapitlet analyseres studentenes samtale etter at de hadde sett assosiasjonene til hver av gruppene.

\section{Studentenes assosiasjoner til begrepene foreldre og innvandrerforeldre}

Antall assosiasjoner i de ulike gruppene varierer fra 4 til 16, men det er mindre forskjell på totalt antall assosiasjoner mellom gruppene som fikk begrepet foreldre og gruppene som fikk begrepet innvandrerforeldre. Som tabell 1 viser er 28 assosiasjoner relatert til begrepet foreldre og 34 assosiasjoner relatert til begrepet innvandrerforeldre.

Tabell 1. Antall assosiasjoner (tallene i parentes viser antallet)

\begin{tabular}{llllll}
\hline $\begin{array}{l}\text { Gruppene som fikk begrepet foreldre } \\
\text { (totalt 28) }\end{array}$ & & $\begin{array}{l}\text { Gruppene som fikk begrepet } \\
\text { innvandrerforeldre (totalt 34) }\end{array}$ & \\
\hline Gruppe 1 (15) & Gruppe 3 (9) & Gruppe 5 (4) & Gruppe 2 (16) & Gruppe 4 (12) & Gruppe 6 (6) \\
\hline
\end{tabular}

Videre presenteres assosiasjonene i hver av kategoriene 'foreldrerollen', 'foreldres bakgrunn' og 'samarbeid skole-hjem' i egne delkapitler.

\section{Foreldrerollen}

Assosiasjonene i kategorien 'foreldrerollen' beskriver det å være foreldre; hvilket ansvar og hvilke oppgaver foreldre har overfor barnet sitt. Tabell 2 viser at det er stor forskjell på hvordan gruppene som fikk begrepet foreldre og gruppene som fikk begrepet innvandrerforeldre vektlegger dette i sine assosiasjoner. 
Tabell 2. Assosiasjoner i kategorien foreldrerollen. (Antall grupper vises i parentes bak assosiasjonen når flere grupper har skrevet det samme.)

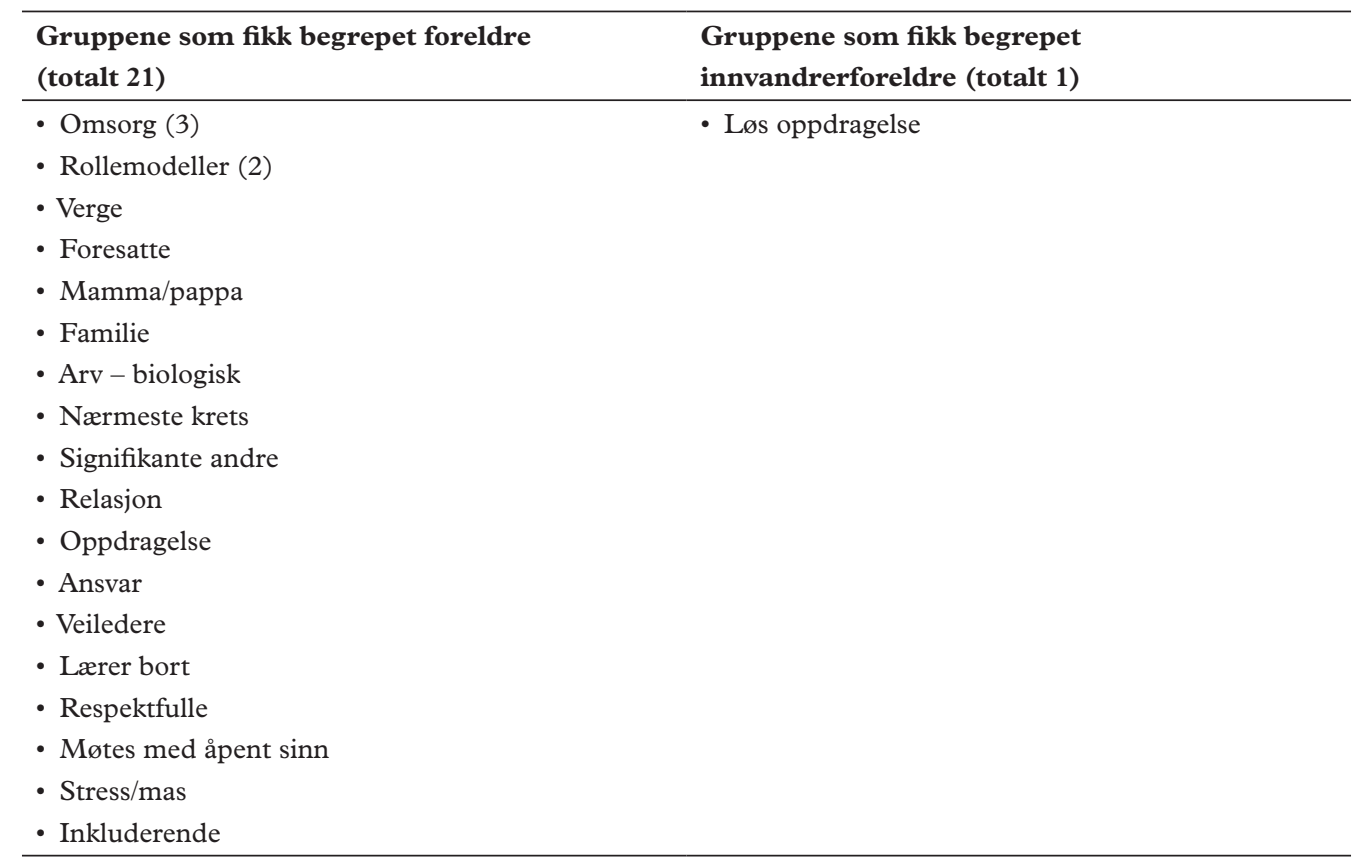

Assosiasjonene i kategorien 'foreldrerollen' tydeliggiør forskjellen mellom studentenes oppfatninger avhengig av om de fikk begrepet foreldre eller innvandrerforeldre. Som tabell 2 viser er kategorien 'foreldrerollen' dominerende hos gruppene som fikk begrepet foreldre med 21 av 28 assosiasjoner (75\%). Disse gruppene knytter sine assosiasjoner til relasjonelle forhold (eks. mamma/pappa), ansvarsforhold (eks. omsorg) og arbeidsoppgaver (eks. veiledere). 'Stress/mas' viser også hvordan studentene mener at oppgaven med å oppdra barn kan erfares. Gruppene som fikk begrepet innvandrerforeldre har kun én assosiasjon som kan knyttes til foreldrerollen. Dette er assosiasjonen 'løs oppdragelse'. Studentene sier her at innvandrerforeldrenes arbeidsoppgave er å oppdra barna sine, men å omtale det som 'løs oppdragelse', kan forstås slik at studentene gir en negativ stereotyp oppfatning av innvandrerforeldres oppdragelsesform.

\section{Foreldres bakgrunn}

I kategorien 'foreldrenes bakgrunn' sier assosiasjonene ingenting om selve foreldreoppgaven, men de beskriver kjennetegn ved 'foreldre' og 'innvandrerforeldre'. Tabell 3 viser hvordan gruppene vektlegger dette.

På samme måte som for kategorien 'foreldrerollen' er det også i kategorien 'foreldrenes bakgrunn' stor forskjell i antall assosiasjoner hos gruppene som fikk begrepet foreldre og gruppene som fikk begrepet innvandrerforeldre. Gruppene som fikk 
Tabell 3. Begreper i kategorien foreldrenes bakgrunn

\begin{tabular}{ll}
\hline $\begin{array}{l}\text { Gruppene som fikk begrepet foreldre } \\
\text { (totalt 1) }\end{array}$ & $\begin{array}{l}\text { Gruppene som fikk begrepet } \\
\text { innvandrerforeldre (totalt 13) }\end{array}$ \\
\hline - Flere kulturer & - Utenlandske \\
& - Kultur \\
& - Etnisitet \\
& - Annen bakgrunn \\
& - Sorg, krise, traume \\
& - Usikre \\
& - Strenge med tanke på religion, høytider osv. \\
& - Heteronormativitet \\
& - Stor familie \\
& - Situasjonssentrert kommunikasjonskultur \\
& - Flerspråklig \\
& - Språk \\
& - Morsmål \\
\hline
\end{tabular}

begrepet foreldre er ikke opptatt av foreldrenes bakgrunn, og de har kun ett begrep, 'flere kulturer', som kan relateres til dette. 'Flere kulturer' kan tolkes slik at studentene vil framheve at foreldre ikke er en homogen gruppe. Gruppene som fikk begrepet innvandrerforeldre har derimot 13 av 34 assosiasjoner (ca. $40 \%$ ) relatert til foreldrenes bakgrunn. Slik jeg forstår disse gruppenes assosiasjoner så vektlegger de også forskjellighet, men da i hovedsak innvandrerforeldres forskjellighet fra foreldre som ikke har innvandrerbakgrunn. Forskjelligheten relateres i hovedsak til 'kultur', 'etnisitet' og 'språk'. Med begrepene 'sorg, krise, traume' og 'usikre', signaliser studentene også at innvandrerforeldre kan ha spesielle utfordringer. Jeg finner det nødvendig å påpeke at selv om foreldreperspektivet i liten grad er tilstede i disse assosiasjonene så kan deres valg vise en bevissthet om mulige hensyn lærere må ta til foreldre med innvandrerbakgrunn.

Jeg vil presisere hvorfor begrepet 'stor familie' er relatert til kategorien foreldrenes bakgrunn, mens 'familie' er plassert i kategorien foreldrerollen. Selv om innvandrerkvinner har hatt betydelig nedgang $\mathrm{i}$ fruktbarheten de siste årene (Statistisk sentralbyrå, 2019) så har mediefokus vært på store barnefamilier blant innvandrere. 'Stor familie' kan derfor tolkes som en stereotypisering av innvandrerforeldre.

\section{Samarbeid skole-hjem}

Skole-hjemsamarbeid er et sentralt tema i grunnskolelærerutdanningen, og det er derfor å forvente at studentene knytter 'foreldre' og 'innvandrerforeldre' til det samarbeidet de som lærere forventer å ha med foreldre. Tabell 4 viser imidlertid at skolehjemsamarbeid hadde langt større fokus hos gruppene som fikk begrepet foreldre enn gruppene som fikk begrepet innvandrerforeldre. 
Tabell 4. Assosiasjonene i kategorien samarbeid skole-hjem. (Antall grupper vises i parentes bak assosiasjonen når flere grupper har skrevet det samme.)

\begin{tabular}{ll}
\hline $\begin{array}{l}\text { Gruppene som fikk begrepet foreldre } \\
\text { (totalt 6) }\end{array}$ & $\begin{array}{l}\text { Gruppene som fikk begrepet } \\
\text { innvandrerforeldre (totalt 20) }\end{array}$ \\
\hline - Samarbeid (2) & - Samarbeid (2) \\
- Møte & - Tilrettelegging \\
- Samtaler/møter & - Krav og rettigheter \\
- Kommunikasjon & - Skape trygghet \\
- Lojalitetskonflikt & - Maktbalanse \\
& - Bruk av tolk (2) \\
& - Språkutfordringer \\
& - Kulturforståelse \\
& - Integrering \\
& - Kulturforskjeller \\
& - Forstålse \\
& - Misforståelser (2) \\
& - Ulike kommunikasjonskulturer \\
& - Ulike verdisyn \\
& - En av de svake foreldregruppene \\
& - Isolert foreldregruppe \\
& - Vil utfordringer forsvinne med generasjoner? \\
\hline
\end{tabular}

Gruppene som fikk begrepet foreldre relaterer 6 av 28 assosiasjoner (ca. $20 \%$ ) til samarbeid skole-hjem. Disse assosiasjonene relateres i hovedsak til skole-hjemsamarbeid generelt, men begrepet lojalitetskonflikt kan tilsi at de har en oppfatning av at det kan være verdikonflikt mellom skolen og hjemmet. Gruppene som fikk begrepet innvandrerforeldre har tre ganger så stor vektlegging på samarbeid skole-hjem med 20 av 34 assosiasjoner (ca. $60 \%$ ). Flere av assosiasjonene kan relateres til utfordringer knyttet til samarbeidet. Dette kan tolkes slik at samarbeid med innvandrerforeldre forstås som mer krevende enn samarbeid med foreldre generelt, men også at studentene viser ekstra omsorg for foreldre som de antar har liten kunnskap om skolen i Norge.

\section{Studentenes assosiasjoner - en oppsummering}

Som jeg har vist over er det tydelig at studentgruppene fikk ulike assosiasjoner avhengig av om de reflekterte rundt begrepet foreldre eller begrepet innvandrerforeldre. Tabell 5 illustrer dette.

Tabell 5. Antall begreper i hver kategori i foreldre- og innvandrerforeldregruppene

\begin{tabular}{lcc}
\hline Kategori & $\begin{array}{c}\text { Gruppene som fikk begrepet } \\
\text { foreldre }\end{array}$ & $\begin{array}{c}\text { Gruppene som fikk begrepet } \\
\text { innvandrerforeldre }\end{array}$ \\
\hline Foreldrerollen & 21 & 1 \\
Foreldres bakgrunn & 1 & 13 \\
Samarbeid skole-hjem & 6 & 20 \\
\hline
\end{tabular}


Tabellen viser at gruppene som fikk begrepet foreldre har hovedvekten av sine assosiasjoner innenfor kategorien 'foreldrerollen', mens gruppene som fikk begrepet innvandrerforeldre har så godt som alle sine assosiasjoner innenfor kategoriene 'foreldrenes bakgrunn' og 'samarbeid skole-hjem'. At assosiasjonene til begrepet innvandrerforeldre i hovedsak knyttes til 'innvandrer' og lite til 'foreldre' må sees i sammenheng med at oppgaven er gjennomført av kommende lærere. Vektleggingen av 'innvandrer' kan forstås som en bevissthet om behov for tilrettelegging $\mathrm{i}$ foreldresamarbeidet.

Resultatene av gruppeoppgaven kan også tolkes slik at studentene har en forståelse av innvandrere generelt som de overfører til begrepet innvandrerforeldre. Studentenes assosiasjoner innebærer en tolkning, og deres generaliseringer bidrar til en stereotypisering som signaliserer bevisste eller ubevisste holdninger som kan skape andregjøring av et utvalg foreldre (Gullestad, 2002; Kjeldstadli, 2008).

\section{Studentenes refleksjoner etter at de har sett resultatene av begrepsoppgaven}

I denne delen presenteres samtalene i de seks gruppene etter at de har sett tabellen med gruppenes assosiasjoner. Det er ingenting i samtalene som tilsier at det var uenighet blant gruppedeltakerne, men studentene samtykker til det den/de andre sier og kommer med nye innspill som bekrefter og/eller utdyper det som er sagt. Analysen presenteres i egne delkapitler systematisert etter kategoriene. Sitatene merkes med FG for de gruppene som fikk begrepet foreldre og IFG for de som fikk begrepet innvandrerforeldre. Nummeret i tillegg er gruppenummeret.

\section{Vektlegging av 'innvandrer' $i$ begrepet innvandrerforeldre}

Alle gruppene, uavhengig av om de har reflektert rundt begrepet foreldre eller innvandrerforeldre, poengterer at de to begrepene gir ulike assosiasjoner. Dette kan eksemplifiserer med dette utsagnet: «Det er jo tydelig at man tenker forskjellig når man hører det ene ordet framfor det andre» (FG1). En av gruppene som fikk begrepet innvandrerforeldre, leser fra tabellen og sier: «man ser veldig tydelig at de som har foreldre har tenkt mer begreper i forhold til det, og vi som har hatt innvandrerforeldre har tenkt mye mer på innvandrere enn på foreldre, dessverre» (IFG2). At studenten avslutter resonnementet med «dessverre» kan tolkes slik at hun mener vektlegging av 'innvandrer' framfor 'foreldre' kan være uheldig, men hun utdyper ikke dette. Dette følges heller ikke opp av de andre på gruppa.

I flere av gruppene påpekes det at begrepet innvandrerforeldre bidrar til fokus på «religion», «kultur» og «språk», og de sier også at dette kan bidra til problemfokus. En student sier: «Man hører jo mye, også hører man kanskje mer om utfordringene enn der hvor det går plettfritt», hvorpå en annen student legger til: «Ja, det gjør man alltid» (IFG4). I fortsettelsen av samtalen sier en av studentene at innvandrerforeldre også kan komme fra Sverige og ikke nødvendigvis fra «muslimske land». De to andre i gruppa reagerer ikke på at studenten bruker begrepet «muslimske land» noe som 


\section{K. Spernes}

kan forstås slik at det er muslimer studentene har i tankene når de snakker om innvandrerforeldre. En i gruppa finner imidlertid en forklaring på hvorfor begrepet innvandrerforeldre assosieres med muslimer: «De er jo enkle å skille ut, og da gjør man vel det». Det er tydelig at denne studenten mener at muslimske foreldre har noe felles som er enkelt å oppfatte. De to andre i gruppa spør ikke hva denne likheten består i noe som kan tolkes slik at dette tas som en selvfølgelighet.

Utsagnene over viser at begrepet innvandrerforeldre kan bidra til generalisering og en stereotyp oppfatning av foreldre med innvandrerbakgrunn. Men det er også flere grupper som sier at 'innvandrer' vektlegges «fordi at du vil jo ta hensyn til de utfordringene som de foresatte kommer med. [...] ja, fokusere på at det skal være inkluderende» (FG1). En av studentene som selv hadde reflektert over begrepet innvandrerforeldre, sier at de satte innvandrerforeldre «veldig i bås» (IFG2). Den andre studenten i gruppa legger til, som en forklaring på den ensidige vektleggingen: «Det har nødvendigvis ikke med fordommer å gjøre, men mest med tanke på tilrettelegging; integrering, tolk, språk». Utsagnet under framhever også at vektlegging av 'innvandrer' skyldes bevissthet om tilrettelegging:

Ja okay, vi skal ikke skille, altså foreldre er foreldre og de har krav på det sammen uansett. Men det er også litt fint at, her er det en gruppe foreldre som kanskje ikke vet alt man har krav på av rettigheter og sånne ting, at det er også fint å se at man er bevisst på det (IFG4).

Selv om jeg vil hevde at studentenes generaliseringer kan synliggjøre en stereotyp oppfatning av innvandrerforeldre, så bekrefter utsagnene over at antakelsen om at studentenes vektlegging av 'innvandrer' i sine assosiasjoner også kan tilsi at de er bevisste at enkelte foreldre trenger en spesiell tilrettelegging.

\section{Foreldre er forskjellige uavhengig av bakgrunn}

Som sagt så kan gruppenes vektleggingen av 'innvandrer' i begrepet innvandrerforeldre bidra til at foreldreperspektivet forsvinner og at studentene får en problemorientert tilnærming til 'innvandrerforeldre'. Fokuset på 'innvandrer' kan også som en av studentene sier, bety at de vektlegger at foreldre er forskjellige: «man skal jo ikke behandle alle likt for da blir det jo urettferdig, og det er jo et godt poeng» (IFG2). En annen student framhever viktigheten av også å ta «hensyn [til de] som er fra Norge». Hun knytter dette spesielt til religiøs tilhørighet:

Hvis du tenker sånn med andre barn da som er fra Norge, de har for eksempel forskjellige religioner, så hensyn må du ta uansett. Du må vise forståelse som lærer, på samme måte som du må vise forståelse til innvandrerforeldre i forhold til deres kultur. Så akkurat den er jo veldig lik uansett (IFG6).

At studenten her vektlegger elever med en religiøs tilhørighet uavhengig av bakgrunn, kan være et forsøk på å minimalisere forskjellen mellom begrepene foreldre 
og innvandrerforeldre. Samtidig kan sitatet tolkes slik at studenten forstår innvandrerforeldre som spesielt religiøse, noe som igjen bidrar til stereotypisering.

En av gruppene leser assosiasjonene slik de står i tabellen og kommenterer at kun én av foreldregruppene har relatert begrepet foreldre, til mangfold: «Det er litt skremmende å se, gruppe 1 nevner flere kulturer, men det er det ingen andre som hadde gjort» (IFG4). Alle gruppene som reflekterte over begrepet innvandrerforeldre og en av gruppene som fikk begrepet foreldre er opptatt av manglende mangfoldsperspektiv hos de som reflekterte over begrepet foreldre. En student poengterer at uansett bakgrunn så er det vesentligste at de er foreldre:

Hovedtyngden er ikke at de er innvandrere. Hovedtyngden er at de er foreldre, og hovedtyngden for norske foreldre eller etnisk norske foreldre er ikke at de er etnisk norske, det er det at de er foreldre. (IFG6)

\section{Studentenes oppfatning av oppgaven}

I gruppesamtalen skulle studentene reflektere over hvilke tanker de får når de ser resultatene av oppgaven. Samtalen under forsøker å gi et inntrykk av studentenes engasjement når de gir uttrykk for sine refleksjoner:

1: Det handler om det at vi på en måte automatisk, kanskje når man hører at det er ...

2: $\quad$ Flerkulturell

1: Ja

2: $\quad$ Så tenker vi liksom mer ...

1: På veldig mye mer da, sånn som dem sa om for eksempel, liksom om kultur og religion og oppdragelse og masse sånn. Liksom masse av det i tillegg da som man også kunne sagt om liksom foreldre generelt og, for det går jo inn under det der

2: $\quad$ Det var liksom mer fokus på det at de var flerkulturelle da. (FG5)

Innholdet i utdraget over kan tilsi at studentene har fått nye tanker om hvordan begrepet innvandrerforeldre framprovoserer tanker om «kultur og religion og oppdragelse og masse sånn». Det er interessant at dette uttrykkes av en av gruppene som selv har reflektert over begrepet foreldre. Pronomenet «vi» kan tilsi at de ikke knytter de spontane assosiasjonene utelukkende til gruppene som fikk begrepet innvandrerforeldre, men at dette kan være representativt også for dem selv. Dette er også tilfelle for en av de andre gruppene som fikk begrepet foreldre. Den ene studenten sier at oppgaven "får oss litt til å reflektere rundt hva begrepene betyr» hvorpå den andre studenten i gruppa sier: «Mm, får deg til å tenke» (FG3). En av studentene som hadde reflektert rundt begrepet innvandrerforeldre sier at hun fikk en «oppvekker».

Så var det jo en oppvekker for min del. At man må virkelig huske på at innvandrerforeldre faktisk er foreldre, dem er omsorgsfulle, du skal ha møte, du skal ha samarbeid, de er de signifikante andre. (IFG2) 


\section{K. Spernes}

Denne studenten vektlegger de assosiasjonene som er framhevet hos gruppene som fikk begrepet foreldre, og sitatet kan tolkes slik at hun mener de som fikk begrepet innvandrerforeldre også skulle ha vektlagt foreldrerollen. Uttrykket «du skal ha møte, du skal ha samarbeid» kan indikere at 'innvandrerforeldre' også ses i sammenheng med skole-hjemsamarbeid.

En av gruppene som diskuterer selve oppgaven sier først at de tror at resultatet ville blitt annerledes om de fikk spørsmål «er det noe forskjell på foreldre og innvandrerforeldre?» (FG3). Gjennom spørsmålsstillingen sier de underforstått at 'foreldre' er noe annet enn 'innvandrerforeldre', og selv om den ene i gruppa først sier at svaret ville vært nei så legger hun til: «eller kanskje religion, og språk selvfølgelig». Den andre i gruppa avslutter med: «Men jeg tenker jo det at oppgaven stiller litt til at vi skal skrive etnisitet». Dette bekreftes med «Mm» etterfulgt av latter før lydfila avsluttes. Selv om studentene i denne gruppa tenker at oppgaven har en bakenforliggende hensikt så tolker jeg det slik at de finner oppgaven verdifull. Det gjør jeg på bakgrunn av at de samme studentene sier at det hadde vært interessant å gjennomføre oppgaven i praksis fordi lærere kan ha andre perspektiver enn det de selv har. Latteren tilsier også at det ikke har gjort vondt for studentene i denne gruppa, å bli bevisst mulige fordommer slik Devine (1989) hevder at det kan gjøre.

\section{Avsluttende betraktninger}

Begrepene foreldre og innvandrerforeldre forstås av studentene som svært ulike kategorier. I den avsluttende betraktningen retter jeg fokuset mot studentenes refleksjoner rundt begrepet innvandrerforeldre. Disse assosiasjonene knyttes i hovedsak til 'innvandrer' og ikke 'foreldre'. Studentene generaliserer for å forstå sammenhenger (jf. Dale, 1993), og refleksjonene kan tyde på at de har en stereotyp oppfatning av enkelte foreldre i skolen (jf. Gullestad, 2002).

Selv om det blir sagt at innvandrerforeldre ikke nødvendigvis kommer fra «muslimske land» så er det tanken om annerledeshet studentene ser ut til å ha når de møter begrepet innvandrerforeldre (jf. Gullestad, 2002; Kjeldstadli, 2008; Vygotsky, 2014). Begrepet knyttes til foreldre som er «enkle å skille ut», og assosiasjonene er religion, kultur, språk og oppdragelse. Studentenes tolking skaper en konstruert virkeligheten om at innvandrerforeldre skaper utfordringer, men kanskje også muligheter, i skole-hjemsamarbeidet (jf. Kjeldstadli, 2008). Dette kan signalisere at begrepet innvandrerforeldre synliggjør både bevisste og ubevisste holdninger (jf. Devine, 1989; Gullestad, 2002).

Gjennom blant annet å trigge studentenes emosjonelle intelligens (jf. Allport, 1979) forsøker oppgaven å bevisstgjøre lærerstudenter hvordan begreper som brukes i skolen kan bidra til generalisering og en stereotyp oppfatning av mennesker. Studien har forsøkt å vise hvorvidt begrepsoppgaven er egnet til dette. Studentenes refleksjoner kan tilsi at stereotypiene automatiseres når de hører begrepet innvandrerforeldre (jf. Devine, 1989). Dersom Gadamer (2010) og Gullestad (2002) har rett i 
at alle mennesker har fordommer, kan de assosiasjonene som framkommer gjennom begrepsoppgaven tilsi at studenter kan ha fordommer mot enkelte foreldre i skolen. Studentenes refleksjoner i samtalegruppene viser imidlertid slik jeg forstår det, at de har fått en bevisstgjøring om hvordan begrepet innvandrerforeldre kan bidra til en ureflektert forståelse av enkelte foreldre (jf. Gullestad, 2002). Denne bevisstgjøringen kan dermed bidra til at enkelte negative fordommer forsvinner (jf. Devine, 1989; Gullestad, 2002).

Som sagt er studien gjennomført i en gruppe på 16 studenter og resultatene kan ikke generaliseres. Det må også legges til at studentene var i oppstarten av emnet Flerkulturell pedagogikk, og det er derfor naturlig at mange av assosiasjonene var rettet mot innvandring. Samme oppgave er imidlertid giennomført $i$ en annen studentgruppe i forbindelse med temaet skole-jemsamarbeid som også viste at studentene assosierer begrepet innvandrerforeldre med 'innvandrer'. Som sagt så ser jeg i etterkant av studentoppgaven at spørsmålet om fordommer kan ha vært ledende. Dersom dette spørsmålet hadde vært unngått så kunne muligens andre perspektiver blitt løftet fram.

Det ville vært interessant å gjennomføre tilsvarende oppgave, men med andre begreper. For eksempel kunne 'foreldre' byttes ut med 'foreldre med norsk bakgrunn' eventuelt at alle gruppene hadde fått både 'foreldre med norsk bakgrunn' og 'foreldre med innvandrerbakgrunn' for å se hvilke eventuelle forskjeller studentene hadde trukket fram. Likeledes kunne oppgaven knyttes til kategorier som brukes på elever, som for eksempel minoritetselev, minoritetsspråklig elev, flerspråklig elev. I etterkant av en slik oppgave ville det også vært interessant om studentene selv finner begreper som de mener kan bidra til generalisering og stereotypisering.

Studentene har gjennom sine erfaringer ulike assosiasjoner til begreper, og de har ulike måter å kategorisere mennesker på (jf. Gullestad, 2002). Slik sett kan det være at begrepsoppgaven bidrar til å konstruere kategorier og dermed også å skape en andregjøring av foreldre (eller elever, som studentene i utgangspunktet ikke har (jf. Gullestad, 2002). Oppgaven krever derfor at det settes av tid til samtale i etterkant.

\section{Takk}

En spesiell takk til studenten som utviklet denne oppgaven og som tillot meg å bruke den videre i undervisning med lærerstudenter. En stor takk også til studentgruppa som ga meg mulighet for å bruke deres resultat av oppgaven samt samtalene i gruppene som data i denne teksten.

\section{Forfatteromtale}

Kari Spernes er dosent ved Høgskolen i Østfold hvor hun underviser grunnskolelærerstudenter i pedagogikk og elevkunnskap. Hun har skrevet flere bøker, bokkapitler og vitenskapelige artikler relatert til flerkulturalitet. Kari Spernes har også mange års erfaring som lærer i barne- og ungdomsskolen. 


\section{K. Spernes}

\section{Referanser}

Allport, G. W. (1979). The nature of prejudice: Unabridged. (25. utg.). Basic Books. (Opprinnelig utgitt 1954)

Antirasistisk senter. (2017). "Vi vil ikke leke med deg fordi du er brun»-En undersøkelse av opplevd rasisme blant ungdom. http://antirasistisk.no/wp-content/uploads/2017/08/Vi-vil-ikke-leke-med-deg-fordi-du-er-brun-enunders $\%$ C3\%B8kelse-av-opplevd-rasisme-blant-ungdom.pdf

Bryman, A. (2016). Social research methods. (5. utg.). Oxford University Press.

Dale, E. L. (1993). Den profesjonelle skole: Med pedagogikken som grunnlag. Ad Notam Gyldendal.

Devine, P. G. (1989). Stereotypes and prejudice: Their automatic and controlled components. Fournal of Personality and Social Psychology, 56(1), 5-18.

Gadamer, H.-G. (2010). Sannhet og metode. Pax Forlag. (Opprinnelig utgitt 1960)

Gullestad, M. (2002). Det norske sett med nye øyne: Kritisk analyse av norsk innvandringsdebatt. Universitetsforlaget.

Kjeldstadli, K. (2008). Sammensatte samfunn - innvandring og inkludering. Pax.

Lenz, C., Nustad, P. \& Geissert, B. (2016). Innledning $i$ Dembra - Faglige perspektiver på demokrati og forebygging av gruppefiendtlighet $i$ skolen. http://dembra.no/no/wp-content/uploads/2016/09/Dembrahefte_2016_1.pdf

Midgley, G. (2000). Systemic intervention. Philosophy, methodology, and practice. Contemporary Systems Thinking, 113-133.

De nasjonale forskningsetiske komiteene. (2021a). Samtykke. https:/www.forskningsetikk.no/ressurser/fbib/ personvern/samtykke/

De nasjonale forskningsetiske komiteene. (2021b). Sentrale krav og hensyn gjennom forskningsprosessen. https:/www.forskningsetikk.no/ressurser/fbib/innforing/hum-sam/

Repstad, P. (1998). Mellom ncerhet og distanse: Kvalitative metoder $i$ samfunnsfag. Universitetsforlaget.

Røthing, Å. (2014). «Er de sinte eller vil de høre på det jeg har å si?» Utsatthet, majoritetsprivilegier og etiske utfordringer i klasserommet. I G. Afdal, Å. Røthing \& E. Schjetne (Red.), Empirisk etikk i pedagogiske praksiser: Artikulasjon, forstyrrelse, ekspansjon (s. 70-88). Cappelen Damm Akademisk.

Røthing, Å. (2015). Rasisme som tema i norsk skole. Analyser av læreplaner og lærebøker og perspektiver på undervisning. Norsk pedagogisk tidsskrift, 99(2), 72-84.

Spernes, K. I. (2014a). En anerkjennende skole? Elever med innvandrerbakgrunn og deres skoleerfaringer. I G. Afdal, Å. Røthing \& E. Schjetne (Red.), Empirisk etikk i pedagogiske praksiser: artikulasjon, forstyrrelse, ekspansjon (s. 177-199). Cappelen Damm Akademisk.

Spernes, K. I. (2014b). Skolens betydning for den lave andelen av ungdom med innvandrerbakgrunn i lærerutdanningen. Tidsskrift for ungdomsforskning, 14(2), 3-27.

Statistisk sentralbyrå. (2019). Fruktbarheten til innvandrerkvinner går ned. https://www.ssb.no/befolkning/artiklerog-publikasjoner/fruktbarheten-til-innvandrerkvinner-gar-ned

Thomassen, W., Malmo, K-A. S. \& Munthe, E. (2017). Lceremiddelbruk og behov i grunnskolelcererutdanning 5-10. Universitetet i Stavanger. https://www.udir.no/globalassets/filer/tall-og-forskning/rapporter/2017/ laremiddelbruk-og-behov-i-grunnskolelarerutdanningen.pdf

Tjora, A. (2017). Kvalitative forskningsmetoder i praksis. Gyldendal Akademisk.

Utdanningsdirektoratet (2016). Identitetsbasert mobbing. https://www.udir.no/laring-og-trivsel/mobbing-ogandre-krenkelser/identitetsbasert-mobbing/

Vygotsky, L. S. (2014/1934). Tenkning og tale. Gyldendal Akademisk. 